\author{
СЛОБОДАНКА ПЕРКУЧИН* \\ Филозофски факултет Универзитета у Новом Саду \\ Нови Сад, Србија
}

\title{
О ИЗУЧАВАњУ ЈЕЗИЧКЕ ДИЈАХРОНИЈЕ НА СТУДИЈАМА РУСИСТИКЕ У СРБИЈИ
}

\begin{abstract}
У раду се сагледава проблематика изучавања језичке дијахроније и наставе дијахронијских предмета на студијама русистике у српској говорној средини. Уз осврт на историјат филолошке и лингводидактичке мисли из дате области, презентују се најновија достигнућа у домену теоријског и емпиријског истраживања система наставе дисциплина лингвистичког историјског подручја код нас, научни радови и иновације у области уџбеничке продукције, те актуелно стање и перспективе изучавања језичке дијахроније на студијама русистике у Србији.
\end{abstract}

Кључне речи: русистика, језичка дијахронија, предмети лингвистичког историјског подручја, српска говорна средина

Српска русистика је у сто педесет година дугој историји изучавања руског језика на универзитету била синхронијски усмерена, али се историјски принцип проучавања језика примењује од самих почетака и зачетника српске лингвистичке русистике, истакнутог слависте и професора Радована Кошутића, а прихваћен је од еминентних научних прегалаца попут П. Митропана, Р. Лалића, Ст. М. Куљбакина, К. Тарановског, Б. Терзића, Р. Маројевића, П. Пипера и др., ${ }^{1}$ док су дијахронијски предмети постали незаобилазан део студијских програма свих универзитетских центара. ${ }^{2}$

*slobaperk@yahoo.com

${ }^{1}$ Пипер, П., Общая характеристика сопоставительных исслеgований русского и сербского языков // Международный симпозиум Проекты по сопоставителному изучению русского и других языков (Белград, 1-4, июня, 2004), редактор Боголюб Станкович. - Београд: Славистичко друштво Србиије, 2004, стр. 244-249.

${ }^{2}$ Студијски центри са српског говорног подручја (Београд, Нови Сад, Косовска Митровица, Источно Сарајево, Бања Лука, Никшић) у курикулумима садрже ужестручне дијахронијске дисциплине (Историјска граматика руског језика, Историја руског / књижевног/ језика) као и предмете шире струке (Старословенски језик, Упоредна граматика словенских језика). 
Историјско-компаративним методом Радован Кошутић је поставио темељ историјском приступу у изучавању руског језика у српској средини, а историјским коментарима у капиталном делу Морфология русского языка, ${ }^{3}$ те упоредном анализом руских, српских и црквенословенских фонетских појава у књизи Фонетиика русскоі̄о язык $a,{ }^{4}$ и увођењем контрастивног принципа у проучавању језика, дао немерљив допринос дубљем проницању у структуру руског и српског језика о чему говори доајен наше славистике Богдан Терзић у научним освртима Лингвистический основ сопоставительного мето gа профессора Раgована Кошутича и Перспективы сербской конфронтативной русистики. ${ }^{5}$

У својим чланцима Оوнос синхроније и gијахроније у настиави рус-

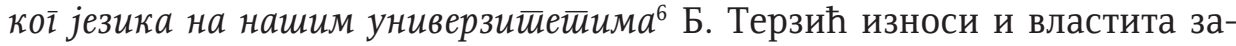
пажања о односу и значају синхроније и дијахроније у настави руског језика на студијама русистике, истичући потребу заснованости наставе страног (руског) језика на научним принципима, успостављања склада између презентовања резултата лингвистичких истраживања и практичног учења језика, као и контрастивног метода у учењу страног језика базираног на језичкој синхронији и дијахронији као научним приступима у нашој високошколској настави.

О улози дијахронијског принципа као динамичког у синхроном /статичком/ проучавању језика, као и развоју мисли о овој проблематици у разним периодима развитка науке о језику, од пред-Сосировског времена до данас, те ставовима савремене науке, особито конфронтационо-контрастивне анализе језика, Б. Терзић говори у студији Некоторые аспекты gиахронического поgхоgа при изучении русского языка как близкоро оственного сербскохорватскому языку. ${ }^{7}$

Уз исцрпан преглед најтипичнијих историзама у руском језику, који имају међујезичко значење у односу на српски, аутор предочава појаве које су идентичне у оба језика, констатује разлике истичући потребу историјског коментарисања, и указује на потребу вршења детаљне упоредне анализе различитих језичких нивоа на плану синхроније двају

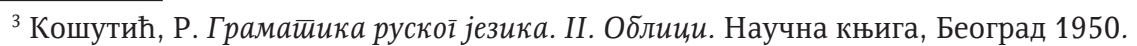

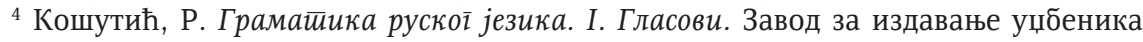
СРС, Београд, 1969.

${ }^{5}$ Терзић, Б. Лингвистический основ сопоставительного метоgа профессора Раgована Кошутииа.; У књ. Руско-српске језичке паралеле, Београд 1999: 33-40.; Перспективы сербской конфронтативной русистики. У књ. Руско-српске језичке паралеле, Београд 1999: 47-53.

${ }^{6}$ Терзић, Б. О онос синхроније и gијахроније у насйави рускої језика на нашим уни-

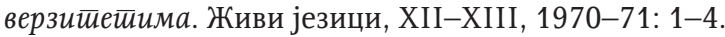

7 Терзић, Б. Некоторые аспекты gиахронического поgхоgа при изучении русско20 языка как близкородственного сербохорватскому языку. Русский язык за рубежом, 2/1985: 61-65. 
језика, те упоређивања пресека савременог српског језика са стањем у извесној етапи развоја староруског језика и то управо оној која највише одговара стању система у савременом српском језику. ${ }^{8}$

Поменути радови, уједно представљају и осврт на ставове светски признатих слависта и лингвиста, нарочито контрастивиста, као што су П. Адамец, П. Шима, Х. Билфелт, В. Барнет, Р. Павлова, Г. П. Ижакевич, А. В. Лагутина, О. Б. Ткаченко и др. ${ }^{9}$ који сматрају да историјски аспект, односно историзми и историјски екскурси, имају важну улогу за изучавање синхроније језика уопште, па тако и руског, што је код нас, приклањајући се кошутићевској традицији, подржала у научном истраживаању у области контрастивног проучавања српског и руског језика и професор Наталија Радошевић. ${ }^{10}$

Од посеб̆не вредности у српској русистичкој мисли је и научни чла-

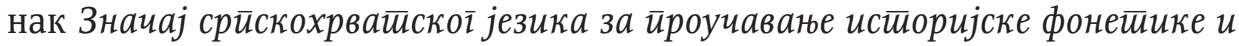
іраматиике рускоі језика, ${ }^{11}$ у којем Богдан Терзић осветљава значај српског (српскохрватског) језика за проучавање историјске фонетике и граматике руског језика, што се надовезује на широко распрострањен став у руској славистици да руски језик треба учити управо пратећи стање у савременом српском језику, будући да је српски језик у многоме архаичнији од руског (В. В. Виноградов, П. С. Кузнецов, Л. А. Булаховски, П. J. Черних и др.), ${ }^{12}$ као и да историју руског језика треба сагледавати и

${ }^{8}$ Као основна категорија архаизације руског језика јужнословенског порекла прате се црквенословенизми на нивоу фонетике, морфологије, творбе речи и лексике, који у српском језику имају потпуно идентичне елементе, евидентирају појаве које су одраз различитог рефлекса старијег стања у два језика и захтевају одговарајуће тумачење процеса и исхода, врши поређење руског и српског акцента везано уз дијахронијски и дијалектолошки план, као и могућност схватања морфолошког принципа руског правописа сагледавањем фонетског српског правописа са морфолошким елементима у дијахронијској перспективи, истиче историјско поређење са српским језиком као чуварем старијег стања, те сагледавају разлике и указује на њихово историјско порекло, а осврће се и на чињеницу да на синтаксичком и лексичком нивоу, такође постоји цео низ појава које треба пропратити историјско-компаративним коментаром. Према: Терзић, Б. Некоторые аспекты gиахронического поgхода при изучении русского языка как близкородственного сербохорватскому языку. У књ. Руско-срйске йаралеле Београд, 1999: $25-29$.

${ }^{9}$ Исто, 24-25.

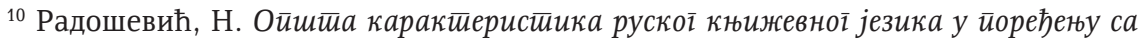
срйскохрвайским. У књ. Руски књиневни језик, Београд 1966.

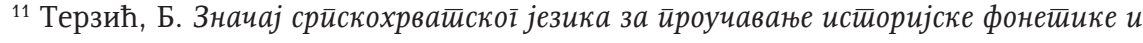

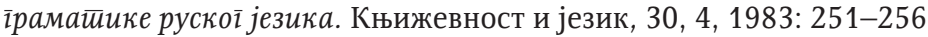

${ }_{12}$ Терзић, Б. Некоторые аспекты gиахронического поgхода при изучении русско20 языка как близкородственного сербохорватскому языку. У књ. Руско-срйске иаралеле. Београд, 1999:29. 
тумачити управо у поређењу са стањем у савременом српском у његовој историјској перспективи. ${ }^{13}$

За проучавање руског и српског, као и староруског, старословенског, односно, прасловенског језика, од значаја су и зборници радова, чланци, студије и граматике руског језика са историјским коментарима дугогодишњег професора универзитета и истраживача у области дијахроније Радмила Маројевића. ${ }^{14}$

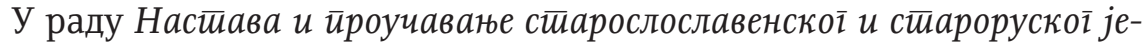
зика на срйским универзитетеим $a^{15}$ Р. Маројевић указује на историјски приступ у извођењу курса старословенског, односно, староруског језика, те даје осврт на методолошко издвајање раног и позног периода старословенског и староруског језика, као и на фонетско-морфолошку структуру курса историје руског језика на српским универзитетима, уз напомену да у оквиру морфолошког курса старословенског и староруског језика посебно место припада проучавању хибридних врста речи - партиципима и посесивима. Изучавање историјске синтаксе у поменутим дијахронијским дисциплинама, по његовим сазнањима, фрагментарно је, пре свега, због ограничености времена, и, углавном се своди на праћење следећих категорија: синтаксичке функције партиципа и посесива, апсолутног датива, двоструких зависних падежа, једночланих реченица, редупликације предлога, посесивног генитива и датива, генитива са предлогом $y$, као и неких других питања.

${ }^{13}$ Розова, 3. Г. Значение сербского языка при изучении исторической грамматики русского языка. - Вопросы славянского языкознания, книга четвёртая, Львов, 1955.

${ }^{14}$ Наводимо само неке од научних чланака Р. Маројевића везаних уз проучавање староруског језика: Историческое словообразование и хронология фонологических изменений // Филологические науки. - 5 (1985), стр. 38-42; Посесивне кайеїорије у „Слову о йолку Иїореве” // Јужнословенски филолог. - 41 (1985), стр. 91-123.3.; Прилози ииворбе-

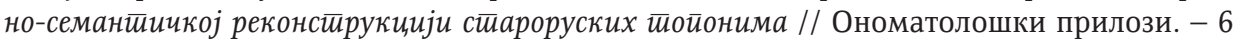

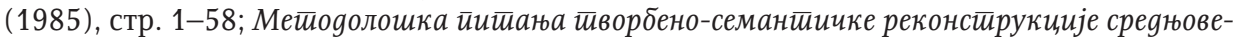
ковних йойонима (на иримеру сйароруских назива іраgова) // Зборник Шесте југословенске ономастичке конференције / главни уредник Павле Ивић. - Београд : Српска академија наука и уметности, 1987. - стр. 135-139.15.; О јеgном йумачењу сйароруских назива ipagoвa // Onomastica Jugoslavica. - 12 (1987), стр. 227-239.; Семантичка gвопланост посесивних извеgенииа типа Иваньковая у староруском језику : (уз тумачења граматике и семантике облика у руској историјској лингвистици) // Зборник Матице српске за филологију и лингвистику. - 37 (1994), стр. 339-346.; Этюgы по грамматике gревнеруского языка. I, (К прочтению Свинцовой грамоты) // Вопросы языкознания. - 3 (1996), стр. 17-22; Мето gологические вопросы реконструки,и яревнеславянских топонимов: gериваиионно-семантический и gериваиионно-фонетический аспекты // Вопросы языкознания.. - 3 (1997), стр. 76-88; Этюgы по грамматике яревнорусского языка. II (посессивы munа Творимиричь). // Вопросы языкознания. - 2 (1998), стр. 51-59. и др.

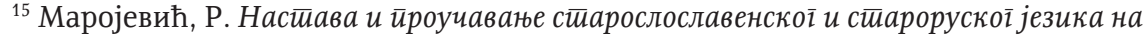
срйским универзитиеиима. Старославенске студије, 2000: 143-150. 
У научној студији Тийолошко gиференцирање руског̄ и срйско-хр-

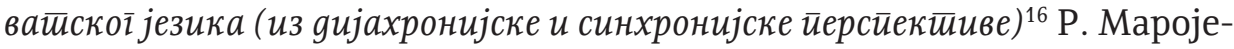
вић се бави важном проблематиком типолошких разлика двају блискосродних језика, руског и српског, са освртом на прасловенско стање, уз примену компаративно-историјске, конфронтационо-контрастивне и типолошке анализе, сагледавајући два словенска језика из историјске перспективе на фонолошком, морфолошком и лексичком, а делом, и деривационом и синтаксичком нивоу, уз осврт на лингвокултуролошки аспект, који се своди на преглед мањег броја релевантних диференцијалних особености, будући да му тек предстоји типолошко истраживање. ${ }^{17}$

Типолошко и историјско поређење на релацији руски-српски језик среће се у виду историјских коментара, с обзиром на ситуацију у савременом руском језику, и у граматикама руског језика, у првом реду, у већ помињаној Граматици Р. Кошутића ${ }^{18}$ и дидактичкој граматици професора Димитрија Ђуровића, ${ }^{19}$ те новијој граматици руског језика Р. Маројевића ${ }^{20}$ што доприноси лакшем усвајању руског језика у настави синхроније за носиоце српског као матерњег.

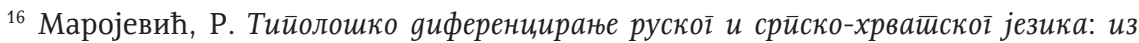
gијахронијске и синхронијске иерсиекиииве / Јужнословенски филолог, XLII, 1986: 21-41.

${ }^{17}$ На фонолошком нивоу руски и српски језик из историјске перспективе сагледавају се на основу заједничког типолошког обележја: губљење назалних вокала; губљење полугласника предњег и задњег реда; престанак прасловенског разликовања вокала по квантитету /o/, /e/ као увек кратки, /a/, /и/, /у/ као увек дуги; упрошћавања вокалског система, губљења фонеме /ё/; губљења фонолошког разликовања између /и/ и /ы/. Типолошке разлике између руског и српског језика на фонолошком плану укључују: умекшавање полумеких сугласника (у руском језику је формирана опозиција меки - тврди сугласник ); преображај тонског у експираторни акценат ( у руском језику довело до редукције вокала и до појаве неутрализације фонолошких опозиција у неакцентованом положају); у српском језику одсуство парних тврдих и меких сугласника; чување тонског акцента; задржавање вокалног /p/; разлике у вокализовању полугласника, остварен прелазак /л/ у /o/, нема преласка /e/ у /o/ као у руском језику, као ни фонолошке диференцијације парних тврдих - меких испред /о/. На морфолошком нивоу разлике су присутне у категорији рода, броја, падежа, категорије аниматности, придевског вида, времена, као и у систему врста речи. У области лексике диференцирање се евидентира код глагола кретања, премештања или налажења предмета у простору, што је типично за руски, а изостаје у српском језику и сл., док деривациони, синтаксички план и лингвокултуролошки по мишљењу Р. Маројевића није довољно испитан. (према Маројевиһ 1986: 21-41).

${ }^{18}$ Кошутић, Р. Грамайика руской језика. II. Облиии. Научна књига, Београд, 1950.

${ }^{19}$ Ђуровић, Д. Руски књижевни језик. Књижарница Геце Кона, Београд, 1931.

${ }^{20}$ Мароевич, Р. (2001) Русская грамматика: Сопоставительная грамматика русског и сербского языков с историческими комментариями: в 2-х томах (Москва - Белград 2001:Международный университет бизнеса и управления, Сербский фонд славянской письменности и культуры). 
Поред изложеног, као значајан допринос за изучавање језичке дијахроније код нас, важно је поменути и пример конфронтационог истраживања у области лексике на савременом, као и историјском плану.

Овим питањем бавила се Вера Николић у Проблемима у насйави руске лексике, која у оквиру свог дискурса, осим праћења руско-српских еквивалената и разлика у савременом језику, посеже и за етимологијом, а у извесним дигресијама упоредно-историјским прегледом лексички материјал смешта у област ширег словенског, а по потреби, и индоевропског језичког ареала. Овакав приступ потврђује значај и потребу комбиновања конфронтационог метода са историјско-компаративним при изучавању лексичко-семантичких категорија руског језика као страног на студијама русистике у неаутентичној, при том, блискосродној (српској) говорној средини што доприноси теоријском и практичном објашњавању лексичког нивоа речи, а самим тим, и лакшем усвајању лексике и фразеологије и њиховој бољој примени у савременом руском, као и адекватном и успешном превођењу на српски језик. ${ }^{21}$

Проблематика изучавања језичке дијахроније са лингводидактичког аспекта, односно система наставе дијахронијских дисциплина на студијама руског језика у неаутентичној говорној средини спада у ред недовољно разрађених и истражених питања филологије и лингводидактике, ${ }^{22}$ тако да је ово подручје до сада остало без студиознијих монографских и дисертационих истраживања у међународним, ${ }^{23}$ а и домаћим оквирима. ${ }^{24}$

${ }^{21}$ Николић, В. Проблеми у настиави руске лексике. Изд. Филолошког факултета у Београду, 1979.

${ }^{22}$ На недовољну истраженост, као и на периферни, архаични карактер и готово архивистички статус предмета језичке дијахроније у настави страног језика указивали су код нас 3. Жилетић и В. Берић-Ђукић, примењено на историју немачког језика. уп.

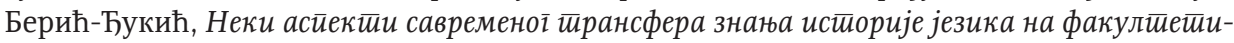

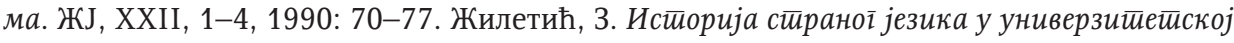
настиави. Анали ФФ, ХІІ, Београд 1976: 541-545.

${ }^{23}$ У Русији, као и широј славистичкој научној јавности, о настави историјских лингвистичких дисциплина у високошколској русистици излагали су еминентни слависти, али су такође, изостале опсежније студије, које би се бавиле системом наставе и сагледавањем улоге, места и значаја, те перспективе наставе историјских лингвистичких дисциплина у страној језичкој, самим тим, и српској средини. УП. Гак, В. Г. Проблемь преподавания русского языка как иностранного филологам-русистам. Доклады советской делегации на 3-м конгрессе МАПРЯЛ. Изд. „Русский язык”, Москва, 1976, 51-67; Горшкова, К. В. О месте исторических филологических gисииллин при поgготовке преподавателя-русиста. Доклады советской делегации на 4-м конгрессе МАПРяЛ. Изд. «Русский язык», Москва, 1979: 13-17; Иванов, Б. Проблемы университетского содержания обучения. Современная высшая школа, 1/1980: 61-66.

${ }^{24}$ Овој констатацији у прилог иде и мишљење академика Предрага Пипера о знатно слабијој заступљености дијахронијског проучавања других словенских језика, у 
У новије време интересовање за језичку дијахронију у српској русистици нашло је свој израз у теоријском и емпиријском истраживању из области система наставе дијахронијских предмета у оквиру последипломских студија што је резултирало израдом и одбраном магистарског рада Слободанке Перкучин под називом Дијахронијске gисиийлине

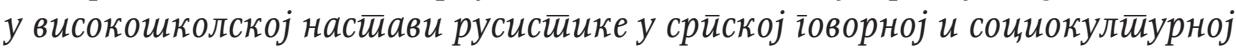
среguнu, ${ }^{25}$ а резултати овог истраживања презентовани су у виду саопштења на научним скуповима, публиковани у филолошким, педагошким и методичким часописима, те нашли место и у изради наставних средстава, односно састављању уџбеника из историје руског језика.

Поменуто дисертационо истраживање представља покушај сагледавања система наставе дијахронијских дисциплина уже струке (Историјска граматика руског језика, Историја руског књижевног језика) као и предмета шире струке (Старословенски језик, Упоредна граматика словенских језика) на русистичким студијама у српској говорној и социокултурној средини.

Истраживање је обухватило сагледавање и дефинисање предикције наставе, односно психолошке претпоставке ${ }^{26}$ и лингводидактичку заснованост наставе ${ }^{27}$ одређивање места дијахронијских дисциплина у структури наставе русистике на универзитету и корелативних веза, ${ }^{28}$ те улоге у општој структури русистичких студија и формирању професионалне компетенције филолога-русисте у српској говорној средини, ${ }^{29}$ као и организацију, концепцију и морфологију наставе, компоненте система наставе - циљеве, задатке, методе, принципе, наставна средства, одабир и презентацију садржаја и сам процес наставе у препаративној, оперативној и евалуационој димензији са циљем унапређења и оптими-

поређењу са проучавањем српског језика, крајем 20-ог века код нас. Уп. Пипер, П. Срӣска

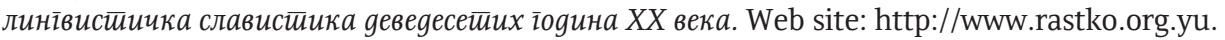

${ }_{25}$ Теза је рађена под коменторством професора др Марије Стефановић и др Ксеније Кончаревић и одбрањена на Филозофском факултету у Новом Саду 2010. године (Библиотека Филозофског факултета, Нови Сад, у рукопису 268 стр.).

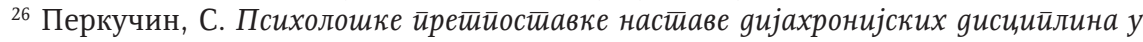
високошколској русистиици у срйској іоворној среgини. Педагошка стварност, бр. 2, Нови Сад, 2012: 269-279.;

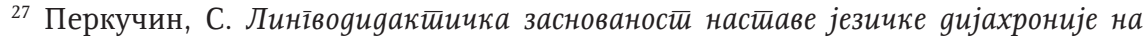

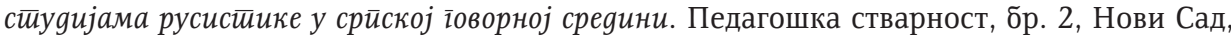
2013: 305-315.

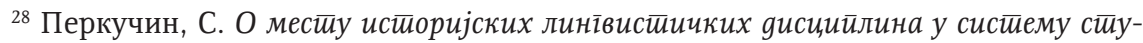
gија филололоїије (русистичке), Методички видици ор. 2, Нови Сад, 2011: 97-101.

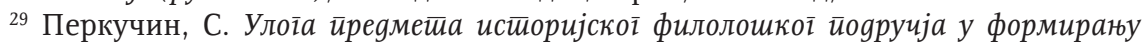
ирофила филолоїа-русистее на нашим универзитетиима. Славистика XV, Београд, 2011: 293-300. 
зације наставе језичке дијахроније из све четири дисциплине понаособ, као и међусобно.

Овим истраживањем остварено је вредновање и процена постојећег стања и сагледана перспектива наставе предмета историјског филолошког циклуса у оквиру славистичких катедри у српској говорној средини, ${ }^{30}$ дате сугестије са предлозима за прецизирање програмских захтева, корекцију актуелних студијских планова и програма и измене у садржају и организацији студијског процеса из све четири дијахронијске дисциплине ${ }^{31}$ а у крајњем домету дат је предлог јединственог и непротивречног теоријског модела система наставе на предметима језичке дијахроније. ${ }^{32}$

Поменуто дисератационо истраживање, како смо већ истакли, нашло је своју примену и у креирању наставних средстава, односно дало допринос стварању прве монографије научно-дидактичког типа из историје руског језика.

Проблематика уџбеничке продукције, састављања и издавања уџбеника на српском језику из ове области (Историјска граматика руског језика и Историја руског/књижевног/ језика) представља посеб́о питање везано уз изучавање и предавање језичке дијахроније у високошколској русистици.

Издања из Историјске граматике руског језика на српском језику, код нас, нажалост, изостају што се, с обзиром на особеност и сложеност грађе, одражава на процес наставе из поменуте историјске дисциплине, како у погледу разумевање и усвајања самих историјских лингвистичких садржаја, тако и њихове примене у изучавању савременог руског језика у неаутентичној говорној средини.

Усамљен, но хвале вредан, пример представљао је својевремено покушај Малика Мулића, професора универзитета и истраживача медиевистике источних и јужних Словена, у погледу састављања уџбеничке трилогије из Историјске граматике руског језика са аспекта историјске фонетике, историјске морфологије и историјске синтаксе. Стицајем околности, објављен је само први део под називом Историјска фонейике

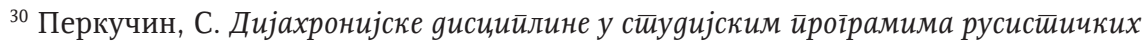
кайеgри у срйској іоворној среgини. Методички видици бр. 1, Нови Сад, 2010: 97-103.

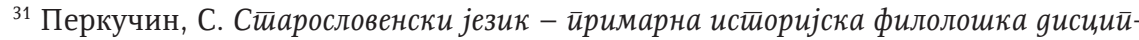
лина на стиуgијама русисиике. Славистика XVI, Београд, 2012: 566-578; Уйореgна іррама-

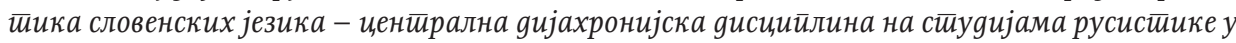

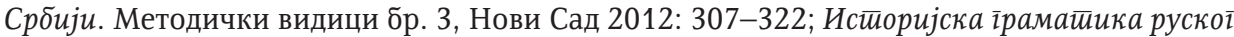
језика - истиоријска филолошка дисиийлина на сииуgијама русистиике. Славистика XVII,

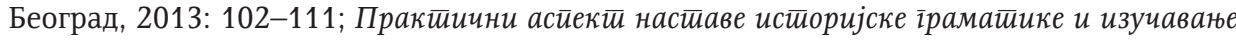
савременої рускої језика. Славистика XVI, Београд, 2012: 380-388.

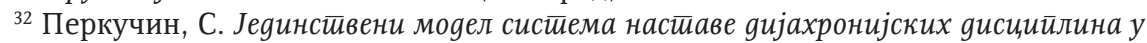
високошколској русистиии у срйској іоворној и сощиокулишурној среgини. Славистика XV, Београд 2011: 325-338. 
рускоі језика, ${ }^{33}$ а будући да је уџбеник писан на руском језику, његова вредност за студенте који руски језик изучавају као нематерњи, састоји се, пре свега, у виду напомена о историјским паралелама са српским (српскохрватским) језиком на нивоу савременог стања, али и историјског, забележеног у споменицима.

За разлику од поменутог, на наше задовољство, можемо истаћи да је ситуација у погледу продукције из Историје руског (књижевног) језика код нас, одскора, знатно повољнија. ${ }^{34}$

Значајну иновацију и важан допринос српској историјској, а самим тим и русистици у целини, представља научна монографија и уџбеник на српском језику намењен проучавању и настави Историје руског (књижевног) језика објављен под називом Истиорија рускої језика (ирквенословенско-срйска иреитлитањ верзитетских професора и наставника Ксеније Кончаревић, Слободанке Перкучин, Марије Марковић и Митре Рељић из више наших русистичких центара (Београд, Нови Сад, Косовска Митровица).

Поменута књига представља први уџбеник из историје руског језика на српском језику у потпуности саображен потребама студената руског језика, чији је матерњи језик српски, али и својеврстан појмовник за стицање свеобухватних знања из језичке дијахроније, будући да, осим историјата формирања историје руског језика као науке, периодизације његовог развоја са посебним акцентом на црквенословенска преплитања у руском и српском језику, те процеса формирања књижевне норме и њене измене кроз историју, садржи и осврт на значај изучавања језичке дијахроније на русистичким студијама, опште теоријско-методолошке појмове везане уз дату област, као и принципе упоредно-историјског проучавања и типолошког диференцирања руског и српског језика из дијахронијске перспективе, основе старословенског и црквенословенског језика, али и преглед вишевековних руско-српских дотицаја.

Овај подухват, према речима аутора, надахнула је „йойеба за ком-

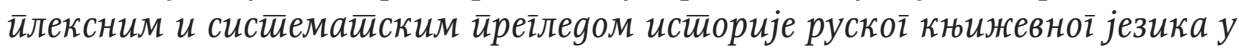

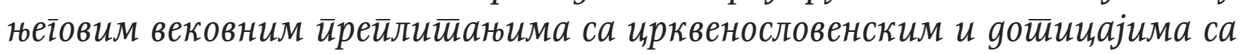

${ }^{33}$ Мулић, М. Исииоријска фонейика рускої језика, Сарајево, 1988.

${ }^{34}$ Не можемо, а да не истакнемо, како је дуги низ година, у недостатку уџбеника из историје руског језика на српском језику, јединствен извор, уз руска издања, за проучавање формирања и развоја словенских књижевних језика, самим тим и руског, представљала књига Предрага Пипера Увоg у славистику, чији је знатан део посвећен управо овој проблематици. (Пипер, П. Увоg у слависиику I, Филолошки факултет, Београд, 1991; прерађено и допуњено издање Увоg у слависииику, Завод за издавање уџбеника, Београд, 1998).

${ }^{35}$ Кончаревић, К. Перкучин С., Марковић М., Рељић М. Исйорија рускої језика (ирквенословенско-руска ирреилитиаюа), Београд, 2016. 
срйским језиком, који би се темелељио на модерним линівистичиким и кул-

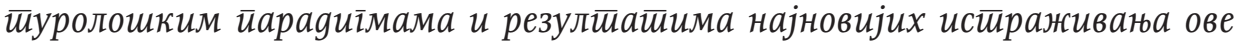

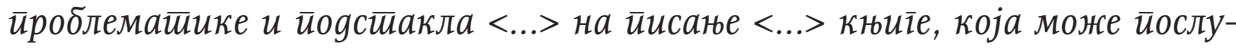

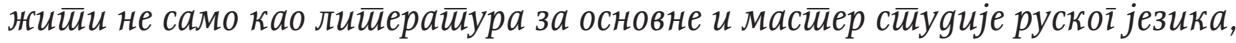

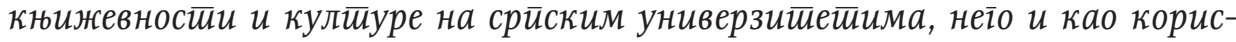

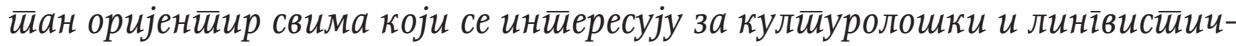

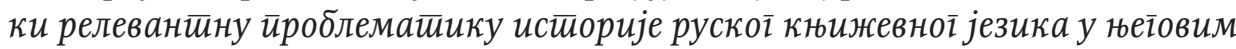
gотиии,јима и везама са ирквенословенским и сриским књиневним језиком og најранијих иеериоgа њеїовоі констиитичисања gо gанас." ${ }^{\prime 6}$

Иновације у домену уџбеничке продукције, као и научно-истраживачка делатност у протеклој деценији, буде наду на плодотворнију будућност изучавања језичке дијахроније, иако актуелна ситуација са тенденцијом ревидирања и укидања предмета и фонда часова, као и дефицит уско специјализованих предавача и последипломаца са звањем магистра и доктора наука из историјске лингвистике наводи на закључак о тренутно релативно скрајнутом статусу језичке дијахроније на русистичким студијама код нас. ${ }^{37}$

Све поменуто може се одразити на судбину дијахроније у будућности, и то у размерама шире славистике, с обзиром да је у последњим деценијама запажена тенденција редуковања и миноризације изучавања историјских лингвистичких садржаја и историјско-компаративног принципа при учењу руског језика на високошколском нивоу не само код нас, већ и шире. ${ }^{38}$

Уз наду о оптимистичној будућности дијахронијске русистике код нас, а из дуга према славистичкој традицији и прегаоцима који су задужили нашу русистику, на крају излагања истакли бисмо чињеницу како управо од данашњег поколења слависта зависи статус и опстанак језичке дијахроније што се одражава не само на изучавање предмета историјског филолошког подручја, већ и на учење савременог руског језика на универзитету, односно на формирање професионалне оспособљености филолога-русисте и његовог филолошког, културног и духовног профила.

${ }^{36}$ Исто, Реи унайpeg (предговор), с. 7.

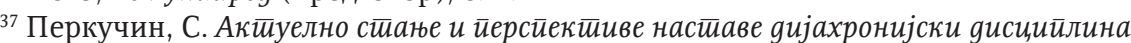
на русистииким сйуяијама у срйској іоворној среgини. 3б: Домети и перспективе развоја славистике (зборник теза). Филозофски факултет у Новом Саду, Интеркатедарска конференција посвећена 50-годишњици Катедре за руски језик и књижевност, Нови Сад 2011: 13-14.

${ }^{38}$ Кречмер, А. О приниипиальной ванности сравнительного поgхода к изучению славянских языков. 3б: Изуиавање словенских језика, књиневностии и кулитура као инословенских и сирани (зборник теза и резимеа), Славистичко друштво Србије, Међународни симпозијум МАПРЈАЛ, Београд 2008 (3-5. јуна): 83-84. 


\section{ЛИТЕРАТУРА}

Берић-Ђукић, В. Неки асиекеии савременог̄ йрансфера знања истиорије језика на факулиетеичма. Живи језици, XXII, 1-4, 1990: 70-77.

Гак, В. Г. Проблемы преповавания русского языка как иностранного филологамрусистам. Доклаgы советской gелегаиии на 3-м конгрессе МАПРЯЛ. Изд. Русский язык, Москва, 1976, 51-67.

Горшкова, К. В. О месте филологических gисииллин при поgготовке препоgавателя-русиста. Доклаяы советской делегации на 4-м контрессе МАПРЯЛ. Изд. Русский язык, Москва, 1979: 13-17.

Ђуровић, Д. Руски књижевни језик. Књижарница Геце Кона, Београд, 1931.

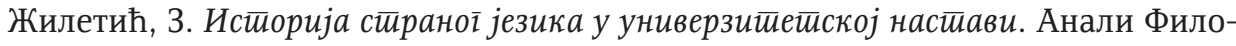
лошког факултета, XII, Београд 1976: 541-545.

Иванов, Б. Проблемы университетского сояержания обучения. Современная высшая школа 1/1980: 61-66.

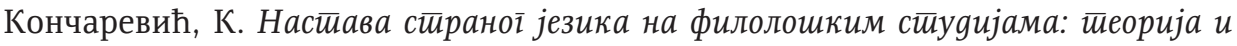
ирракса. Филолошки факултет, Београд, 1996.

Кончаревић, К. Савремена настиава рускої језика: саяржаји, орїанизаиија, облиuи. Београд: Славистичко друштво Србије, 2004.

Кошутић, Р. Грамайика руской језика. І. Гласови. Завод за издавање уџбеника СРС, Београд, 1969.

Кошутић, Р. Грамайика руской језика. II. Облиии. Научна књига, Београд 1950.

Кречмер, А. О принципиальной важности сравнительного поgхоgа к изуиению славянских языков. 3б: Изуиавање словенских језика, књижевностии и кулйура као инословенских и сиррани (зборник иееза и резимеа), Славистичко друштво Србије, Међународни симпозијум МАПРЈАЛ, Београд 2008 (3-5. јуна): 83-84.

Маројевић, Р. Тийолошко gиференцираюе рускоі̄ и срйско-хрвайскої језика /из gијахронијске и синхронијске иерсиекеииве/.Јужнословенски филолог, XLII, 1986: 21-41.

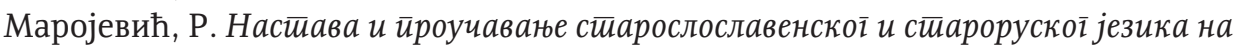

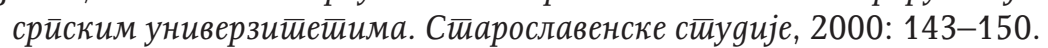

Маројевић, Р. Историческое словообразование и хронология фонологических изменений // Филологические науки. - 5 (1985), стр. 38-42.

Маројевић, Р. Посесивне кайеі̄орије у „Слову о полку Игореве” // Јужнословенски филолоі. - 41 (1985), сиир. 91-123.

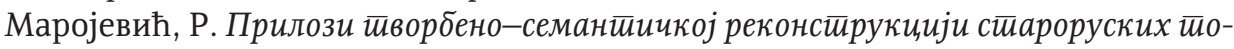
йонима. // Ономатолошки прилози. - 6 (1985), стр. 1-58.

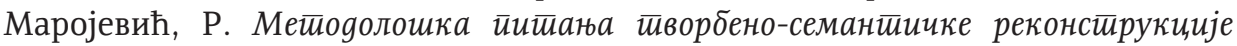

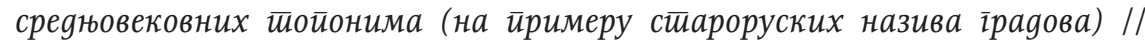
Зборник Шесте југословенске ономастичке конференције / главни уредник Павле Ивић. - Београд : Српска адемија наука и уметности, 1987. - стр. 135-139.

Маројевић, Р. О јеgном йумачеюу сииароруских назива ірраgова // Onomastica Jugoslavica. - 12 (1987), стр. 227-239. 


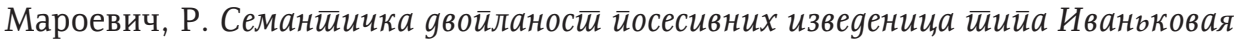

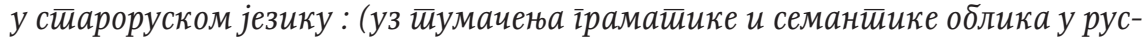
кој истиоријској ленівистищи) // Зборник Матице српске за филологију и лингвистику. - 37 (1994), стр. 339-346.

Мароевич, Р. Этюяы по грамматике древнеруского язука. I, (К прочтению Свини,овой грамоты) // Вопросы языкознания. - 3 (1996), стр. 17-22.

Мароевич, Р. Мето оологические вопросы реконструкиии яревнеславянских топонимов: еривационно-семантический и деривационно-фонетический аспекты // Вопросы языкознания. - 3 (1997), стр. 76-88.

Мароевич, Р. Этюоы по грамматике gревнорусского языка. I (посессивы типа творимиричь). II. (посессивы типа творимиричь) // Вопросы языкознания. - 2 (1998), стр. 51-59.

Мароевич, Р. Русская грамматика: Сопоставительная грамматика русского и сербского языков с историческими комментариями: в 2-х томах (Москва - Белград 2001: Международный университет бизнеса и управления, Сербский фонд славянской письменности и культуры).

Младеновић, А. Славеносрйски језик. Књижевна заједница Новог Сада, Нови Сад, 1989.

Мулић, М. (1988) Истиоријска фонетиика руской језика (Сарајево: Свјетлост) .

Николић, В. Проблеми у насииави руске лексике. Изд. Филолошког факултета у Београду, 1979.

Перкучин, С. Дијахронијске gисиийлине у сииуgијским йроїрамима русистичиких катеиери у срйској іоворној среgини. Методички видици бр. 1, Нови Сад, 2010: 97-103.

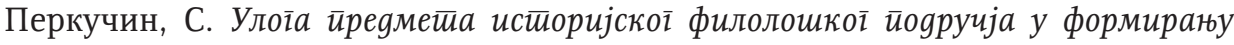
йрофила филолоїа-русисиее на нашим универзитетеичма. Славистика XV, Београд 2011: 293-300.

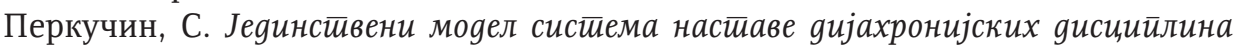
у високошколској русистици у срисккој іоворној и соииокултиурној среgини. Славистика XV, Београд, 2011: 325-338.

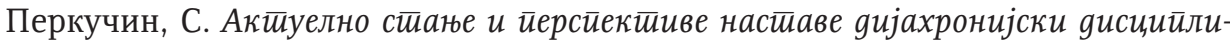
на на русистичким сйуяијама у срйској іоворној среgини. Зб: Дометии и

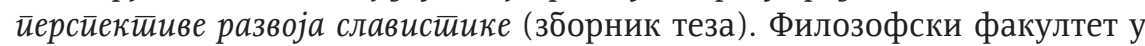
Новом Саду, Одсек за славистику, Интеркатедарска конференција посвећена 50-годишњици Катедре за руски језик и књижевност, Нови Сад, 2011: 13-14.

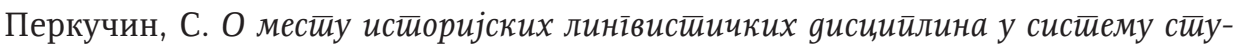
guја филололоїије (русистике), Методички видици бр. 2, Нови Сад 2011: 97-101.

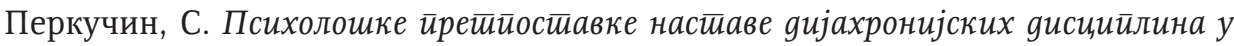
високошколској русистииии у срйској іоворној среgини. Педагошка стварност, бр. 2, Нови Сад, 2012: 269-279.

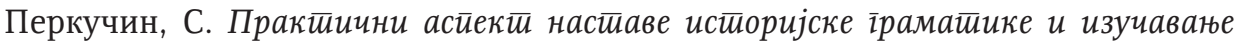
савременої рускої језика. Славистика XVI, Београд, 2012: 380-388. 
Перкучин, С. Сйарословенски језик - иримарна истиоријска филолошка gисиийлина на стиуgијама русистике. Славистика XVI, Београд, 2012: 566-578.

Перкучин, С. Уйореgна ірамайика словенских језик - иенитрална gијахронијска gисиийлина на стиуяијама русистике у Србији. Методички видици бр.3, Нови, 2012: 307-322.

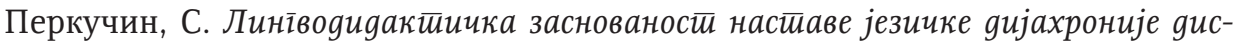
иийлина на сииуяијама русистиике у срйској іоворној среgини. Педагошка стварност, бр. 2, Нови Сад, 2013: 305-315.

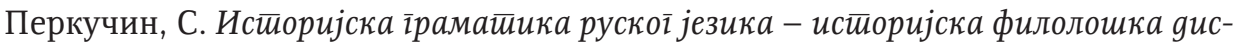
иийлина на сйуgијама русистичке. Славистика XVII, Београд 2013: 102 111.

Пипер, П. Общзая характеристика сопоставительных исслеgований русского и сербского языков // Международный симпозиум «Проекты по сопоставителному изучению русского и других языков» (Белград, 1-4, июня, 2004), редактор Боголюб Станкович. - Београд: Славистичко друштво Србије, 2004, стр. 244-249.

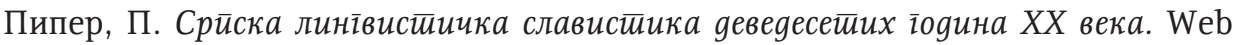
site: http://www.rastko.org.yu.

Пипер, П. Увоg у славистикку I. Филолошки факултет, Филолошки факултет, Београд 1991; друго, прерађено и допуњено издање, Завод за издавање уџбеника, Београд 1998.

Пражский лингвистический кружок (сост., ред. и предисловие Н. А. Кондрашов). Изд. Прогресс, Москва, 1967.

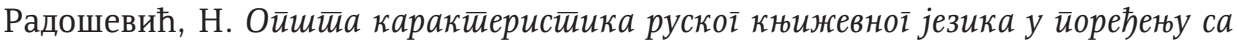
срйскохрвайским. У књ: Руски књижевни језик, Завод за издавање уџбеника СР Србије, Београд, 1966.

Розова, З. Г. Значение сербского языка при изучении исторической грамматики русского языка. - Вопросы славянского языкознания, книга 4-ая, Львов, 1955.

Терзић, Б. Оянос синхроније и gијахроније у настиави рускої језика на нашим уни-

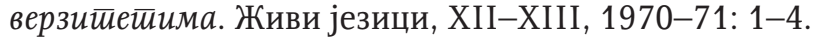

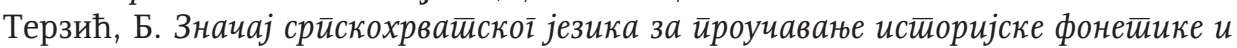
іррамайике рускої језика. Књижевност и језик, 30, 4, 1983: 251-256.

Терзић, Б. Некоторые аспекты gиахронического поgхоgа при изучении русского языка как близкородственного сербохорватскому языку. Русский язык за рубежом, 2/1985: 61-65.

Терзић, Б. Руско-срйске језичке йаралеле. Славистичко друштво Србије, Београд, 1990.

Ткаченко, О. Б. Сопоставительно-историческое изучение славянских языков. Вопросы языкознания, 1/1981: 48. 
Slobodanka Perkučin

\section{ON THE RESEARCH OF LINGUISTIC DIACHRONIA IN RUSSISTIC STUDIES IN SERBIA}

\section{Summary}

The paper examines the problems of studying linguistic diachronia and teaching diachronic subjects in Russian language studies in the Serbian language environment. With the overview of the history of philological and linguodidactical thought from the given area, the latest achievements in the field of theoretical and empirical research of the system of teaching the historical philological disciplines, the scientific papers and innovations in the field of textbook production, as well as the current state and perspectives of studying linguistic diachronia in Russian language studies in Serbia are presented.

Key words: Russistic studies, university education, linguistic diachronia, Serbian spoken environment 